\title{
PEMBERDAYAAN POKDARWIS DESA KEMLOKO DALAM PENGEMBANGAN DESA WISATA MELALUI PELATIHAN BAHASA INGGRIS FOR TOURISM
}

\author{
Neni Wahyuningtyas ${ }^{1}$, Nurul Ratnawati ${ }^{2}$, Idris ${ }^{3}$ \\ ${ }^{1,2,3}$ Prodi Pendidikan IPS, Universitas Negeri Malang
}

e-mail: neni.wahyuningtyas.fis@um.ac.id,nurul.ratnawati.fis@um.ac.id, idris.fis@um.ac.id

\begin{abstract}
Abstrak
Masih rendahnya kemampuan berbahasa inggris yang dimiliki masyarakat Desa Wisata Kemloko merupakan masalah serius yang perlu segera diberikan solusi. Apalagi dengan antusiasme wisatawan mancanegara yang datang berkunjung ke desa wisata ini untuk melihat berbagai atraksi wisata. Atas dasar tersebut, menjadi penting kiranya untuk dilakukan pelatihan bahasa inggris agar mereka terampil menggunakan bahasa inggris. Metode pengabdian masyarakat ini dikembangkan dengan menggunakan pendekatan partisipatif. Hasil kegiatan pengabdian menunjukkan bahwa masyarakat Kemloko dalam mengikuti pengabdian terlihat antusias. Hal ini terlihat dari upaya peserta untuk mengikuti pelatihan di tengah kegiatan sehari-hari yang padat. Peserta selalu berupaya meluangkan waktu untuk mengikuti pelatihan ini setiap minggunya. Berdasarkan hasil akhir kegiatan diketahui rata-rata nilai tes evaluasi peserta adalah 72,28 . Nilai tertinggi yaitu 80 , sedangkan nilai terendah yang dicapai oleh peserta yaitu 60. Dari 15 peserta pengabdian, 6 orang peserta memperoleh nilai antara rentang 72-75, dan 3 orang memperoleh nilai di rentang $>76$. Hasil nilai tersebut menyimpulkan bahwa peserta telah memahami keseluruhan materi pelatihan bahasa inggris dengan baik dan pengabdian masyarakat dikatakan berhasil.
\end{abstract}

Kata kunci: Pelatihan, Bahasa Inggris, Kemloko.

\begin{abstract}
The low level of English language skills possessed by the people of Kemloko Tourism Village is a serious problem that needs immediate solutions. Especially with the enthusiasm of foreign tourists who come to visit this tourist village to see various tourist attractions. On this basis, it is important to conduct English language training so that they are skilled in using English. This community service method was developed using a participatory approach. The results of the service activities show that the Kemloko community in participating in the service looks enthusiastic. This can be seen from the efforts of the participants to take part in the training amidst their busy daily activities. Participants always try to take the time to attend this training every week. Based on the final results of the activity, it is known that the average score of the participant evaluation test was 72.28. The highest score was 80 , while the lowest score achieved by participants was 60 . Of the 15 community service participants, 6 participants scored between $72-75$, and 3 people scored in the range $>76$. The results of these scores conclude that the participants have understood the entire English training material well and that community service is said to be successful.
\end{abstract}

Keywords: Training, English, Kemloko.

\section{PENDAHULUAN}

Prospek industri pariwisata di Indonesia saat ini sangat menjanjikan. Pariwisata memberikan kontribusi yang besar untuk keuangan negara. Dari sebuah sektor pariwisata akan memberikan manfaat yang besar diantaranya yaitu penyerapan tenaga kerja, peningkatan taraf hidup masyarakat, peningkatan produk daerah ke ajang internasional, dan lain 
sebagainya. Salah satu jenis wisata yang saat ini sedang digemari oleh wisatawan yaitu pariwisata yang menyuguhkan alam pedesaan. Alasan tersebut yang memulai berkembangnya konsep pariwisata yang disebut dengan desa wisata. Menurut Nuryanti (1993) desa wisata merupakan bentuk integrasi antara atraksi, akomodasi, dan fasilitas pendukung yang disajikan dalam suatu struktur kehidupan masyarakat yang menyatu dengan tata cara dan tradisi yang berlaku. Salah satu desa wisata yang saat ini mulai dibentuk yaitu Desa Wisata Kemloko.

Desa Kemloko merupakan salah satu desa yang berada di dalam wilayah Kecamatan Nglegok Blitar Jawa Timur, berjarak 2,8 km ke arah barat dari ibukota kecamatan Nglegok, $23 \mathrm{~km}$ dari ibukota kabupaten Blitar. Desa ini berada di lereng gunung Kelud. Desa ini tidak hanya terkenal dengan berbagai keindahan wisata alamnya saja, namun wisata budaya juga masih sangat kental. Desa ini masih memegang teguh falsafah hidup dan kearifan lokal budaya jawa Mataraman. Selain kental dengan budaya Mataraman, Desa Wisata Kemloko juga memiliki daya tarik human interest melalui edukasi mengolah gula jawa, kakao dan kopi. Keberadaan gula jawa merupakan warisan budaya yang sudah ada sejak era Kerajaan Majapahit yang masih banyak ditekuni sebagai pekerjaan di Kemloko. Sementara itu, di bidang agrobisnis pengunjung akan mendapatkan edukasi tentang tanaman kopi dan kakao. Yang mana kopi dan kakao di Kemloko merupakan salah satu komoditas unggulan mayoritas masyarakat di desa wisata tersebut. Selain itu, di Desa Wisata Kemloko ini juga menawarkan homestay dengan suasana pedesaan yang masih asri. Masyarakat di Desa Kemloko masih memegang teguh budaya Jawa sehingga pengunjung yang menginap mendapatkan kesan tersendiri hingga betah berhari-hari bahkan berbulan-bulan di desa Wisata Kemloko.

Potensi pariwisata yang beragam di Desa Wisata Kemloko membuat banyak wisatawan datang untuk berwisata ke tempat tersebut. Setiap bulannya diperkirakan jumlah pengunjung di desa wisata ini terus meningkat, terutama pada musim liburan. Namun, peningkatan jumlah wisatawan berbanding terbalik dengan peningkatan kualitas SDM di sekitar tempat wisata tersebut. Oleh karena itu, setiap pembangunan desa wisata perlu diikuti dengan sarana dan prasarana yang mendukung. Sarana dan prasarana tersebut difungsikan untuk menunjang kemajuan dari desa wisata Kemloko. Salah satu hal yang diperlukan yaitu peningkatan SDM yang berada di sekitar Desa Wisata Kemloko. Salah satu SDM yang perlu ditunjang kemampuannya yaitu anggota Kelompok Sadar Wisata (Pokdarwis) Desa Kemloko. Kemampuan anggota Kelompok Sadar Wisata (Pokdarwis) Desa Kemloko perlu dikembangkan dalam segala aspek. Hal ini karena anggota Kelompok Sadar Wisata (Pokdarwis) Desa Kemloko akan menjadi tour guide ketika ada wisatawan yang datang. Menurut Egar (2017) dan Yoeti (1991) mendefinisikan pramuwisata atau pemandu wisata (tour guide) sebagai seseorang yang bertugas menemani, memberikan informasi, bimbingan, dan saran kepada wisatawan dalam melakukan aktivitas wisatanya. Oleh karena itu seorang tour guide harus diberikan pelatihan yang mumpuni sehingga dapat menjamu wisatawan dengan baik. Sebab suatu tempat wisata akan maju dan berkembang ketika didukung oleh tour guide yang baik pula.

Banyak faktor yang dapat mendukung pengembangan potensi pariwisata di Desa Wisata Kemloko. Namun ada salah satu kendala yang menjadi sebuah hambatan dalam upaya tersebut. Satu kendala yang dimaksud yaitu rendahnya kemampuan berbahasa inggris para tour guide di Desa Wisata Kemloko. Masyarakat yang tergabung dalam Kelompok Sadar Wisata (Pokdarwis) Desa Kemloko ini rata-rata hanya lulusan sekolah dasar (SD) sehingga sebagian besar dari mereka tidak bisa berbahasa inggris. Oleh karena itu diperlukan upaya pengembangan dalam pendalaman berbahasa inggris di anggota pokdarwis ini. Sebab wisatawan yang berkunjung ke Desa Wisata Kemloko tidak hanya wisawatan dalam negeri, namun wisatawan luar negeri juga tidak menutup kemungkinan untuk berkunjung di desa wisata tersebut. 
Permasalahan masih rendahnya pengetahuan serta keterampilan berbahasa inggris yang dihadapi oleh masyarakat Desa Wisata Kemloko perlu mendapatkan perhatian serius. Kondisi inilah yang dirasa sangat menyulitkan bagi para anggota pokdarwis apabila dihadapkan pada wisatawan asing yang tengah berkunjung terutama saat melakukan interaksi. Kesulitan dalam berinteraksi pada saat berhadapan dengan wisatawan asing dapat berdampak pada kualitas pelayanan yang tidak maksimal bagi pengunjung asing.

Kemampuan berbahasa inggris para anggota kelompok sadar wisata (pokdarwis) Desa Kemloko perlu ditingkatkan. Solusi yang dapat diterapkan yaitu penyelenggaraan pelatihan dan pendampingan bahasa inggris komunikatif bagi tour guide. Setidaknya para tour guide ini dapat mengetahui dasar-dasar berkomunikasi yang baik dengan berbahasa inggris. Hal ini dimaksudkan untuk mempermudah komunikasi antara wisatawan dengan tour guide di Desa Wisata Kemloko. Kemampuan bahasa inggris yang mumpuni maka akan membuat wisatawan asing senang berkunjung di desa wisata ini. Program pelatihan yang berkelanjutan dan konsisten akan memberikan dampak yang signifikan dalam upaya peningkatan kualitas berkomunikasi bahasa Inggris pokdarwis. Dengan banyaknya wisatawan yang datang maka kegiatan perekonomian di Desa Wisata Kemloko ini juga akan terus berkembang dan menuju taraf yang lebih baik lagi.

Pada kegiatan pengabdian masyarakat kali ini, kelompok sadar wisata (pokdarwis) Desa Kemloko akan diajak melakukan diskusi dan pelatihan untuk pendalaman berbahasa inggris, sehingga ketika ada wisatawan luar negeri yang datang para anggota pokdarwis ini tidak kebingungan mencari orang untuk memberikan translate bahasa.

\section{METODE}

Metode yang diterapkan dalam pengabdian ini adalah dengan mengungkap permasalahan yang muncul di kalangan para kelompok sadar wisata (pokdarwis) terkait kelancaran berbahasa inggris, kemudian dilakukan diskusi pengusul bersama mitra untuk merumuskan akar masalah prioritas yang disepakati, serta menentukan solusi yang tepat. Namun sebelum dilakukan diskusi atau pelatihan, terlebih dahulu pengusul melakukan koordinasi dengan anggota kelompok sadar wisata (pokdarwis), koordinasi berkaitan dengan kegiatan sosialisasi, terutama mengenai tempat dan jadwal pelaksanaan, serta perlengkapan dan bahan yang harus dipersiapkan peserta sebelum mengikuti kegiatan pelatihan. Adapun rancangan penyelesaian masalah dari kegiatan pengabdian masyarakat ini sebagai berikut:

1. Analisis Situasi dan Persiapan

Beberapa hal yang dilakukan pada tahap awal yaitu (a) Survei lokasi untuk penentuan tempat yang digunakan selama pelatihan (b) Menganalisa kegiatan sehari-hari anggota Kelompok Sadar Wisata (Pokdarwis) di Desa Wisata Kemloko (c) Mengidentifikasi masalah komunikasi yang dialami anggota Kelompok Sadar Wisata (pokdarwis) di Desa Wisata Kemloko (d) Menyusun Buku Saku (Pocket Book) bahasa inggris berdasarkan analisa permasalahan yang didapatkan.

2. Sosialisasi

Sosialisasi diberikan dengan melibatkan perangkat desa dan pengelola pariwisata serta anggota Kelompok Sadar Wisata (pokdarwis) untuk menginformasikan program apa yang akan dilaksanakan, sasaran, dan capaian yang didapat selama pelaksanaan program ini.

3. Pelaksanaan

Pelatihan dilakukan dengan tiga tahap yaitu pelatihan bahasa Inggris komunikatif, pendampingan lapangan dan evaluasi. Pihak dari Universitas Negeri Malang yang disini bertindak sebagai pembuat program akan melakukan pelatihan melalui pendampingan lapangan secara rutin kepada anggota Kelompok Sadar Wisata (pokdarwis) di desa Kemloko supaya instruktur/pelatih dapat dengan mudah memberikan bantuan apabila terdapat permasalahan dalam menggunakan bahasa inggris. Kegiatan pengabdian masyarakat ini 
sangat berkaitan dengan kebutuhan anggota kelompok sadar wisata (pokdarwis) Desa Kemloko, yaitu adanya kemampuan berbahasa inggris yang fasih guna menghadapi para wisatawan asing yang datang. Dengan adanya pelatihan ini, diharapkan anggota kelompok sadar wisata (pokdarwis) Desa Kemloko tidak lagi merasa takut dan kebingungan ketika mendapatkan wisatawan asing yang datang. Dengan kegiatan pengabdian ini maka anggota kelompok sadar wisata (pokdarwis) Desa Kemloko akan memiliki pengetahuan dan keterampilan yang lebih mumpuni dalam berbahasa inggris. Sehingga kedepannya desa wisata ini akan semakin unggul dengan anggota kelompok sadar wisata (pokdarwis) yang mumpuni dan berkualitas.

4. Evaluasi Kegiatan

Tahap evaluasi dilakukan sebagai akhir dari kegiatan untuk melihat sejauh mana keberhasilan kegiatan pelatihan dan pendampingan dilaksanakan. Apabila dalam kegiatan evaluasi ini terjadi kegagalan maka akan dilakukan kegiatan ulang mulai dari persiapan hingga evaluasi kembali.

\section{HASIL DAN PEMBAHASAN}

\section{(1) Hasil Kegiatan}

Kegiatan pengabdian "Pelatihan

Bahasa Inggris For Tourism" ini sesuai rencana dilakukan setiap minggu (8 kali pertemuan) sejak tanggal 15 Agustus 2020 - 11 Oktober 2020. Alhamdulillah sesuai rencana kegiatan pengabdian berjalan dengan lancar. Adapun proses yang kami lakukan sebelum kegiatan tersebut terselenggara yaitu tim memulai dari menganalisis situasi dan persiapan sebagai langkah awal. Dalam tahap persiapan ini tim melakukan survei lokasi untuk penentuan tempat yang digunakan selama pelatihan. Berdasarkan hasil survei kami mendapatkan kesepakatan dengan pihak pokdarwis untuk tempat pelaksanaan kegiatan di rumah Pak Jadi selaku ketua dari pokdarwis.

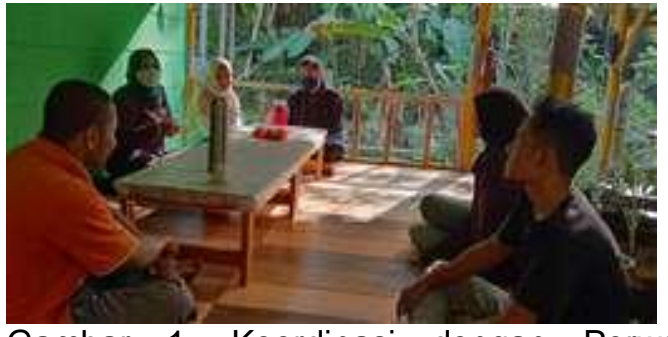

Gambar 1. Koordinasi dengan Perwakilan Pokdarwis.

Langkah selanjutnya yaitu tim menganalisa kegiatan sehari-hari anggota Kelompok Sadar Wisata (pokdarwis) di Desa Wisata Kemloko. Berdasarkan hasil wawancara dengan $\mathrm{Bu}$ lin dan Mas Fendy selaku perwakilan pokdarwis diketahui bahwa mayoritas anggota pokdarwis bekerja sebagai petani, buruh pabrik rokok dan 2 orang sebagai PNS. Oleh sebab itulah dengan melihat kondisi tersebut maka kami menyepakati kegiatan dilangsungkan setiap hari Minggu agar tidak mengganggu aktivitas bekerja dari anggota pokdarwis sebagai sasaran kegiatan pengabdian. Berikutnya, tim mengidentifikasi masalah komunikasi yang dialami anggota Kelompok Sadar Wisata (Pokdarwis) di Desa Wisata Kemloko. Dari hasil identifikasi ini diketahui bahwa anggota pokdarwis ada yang sudah paham bahasa inggris dan ada sebagian besar yang belum familiar dengan bahasa inggris. Oleh sebab itu guna memudahkan dalam pelaksaan pengabdian, tim memutuskan menyusun buku saku (Pocket Book) bahasa inggris sebagai sumber belajar peserta.

Tahap kedua yang dilakukan tim pengabdian yaitu melakukan sosialisasi. Sosialisasi ini diberikan kepada perangkat desa dan pengelola pariwisata serta anggota Kelompok Sadar Wisata (Pokdarwis) untuk menginformasikan program apa yang akan dilaksanakan, sasaran, dan capaian yang didapat selama pelaksanaan program ini. Dalam tahap ini tim pengabdian berusaha meyakinkan anggota Kelompok Sadar Wisata (pokdarwis) Desa Kemloko untuk bersedia mengikuti serangkaian pelatihan sampai akhir. Hal ini menjadi sangat penting untuk dilakukan. Karena kita ketahui bersama bahwa selama ini bahasa inggris dianggap sebagai momok yang menakutkan bagi 
sebagian orang. Jadi dengan adanya kegiatan sosialisasi ini kami memotivasi dan menyemangati anggota pokdarwis bahwa belajar bahasa inggris itu menyenangkan.

Tahap yang ketiga yaitu tahap pelaksanaan, tahap ini merupakan tahap puncak dari serangkaian tahapan. Dalam tahap ini, masyarakat akan diberikan pelatihan secara mendalam selama 8 kali pertemuan. Tim pengabdian dari Universitas Negeri Malang bertindak sebagai pembuat program mengadakan pelatihan melalui pendampingan lapangan secara rutin kepada anggota Kelompok Sadar Wisata (pokdarwis) di desa Kemloko. Sejak tanggal 15 Agustus 2020 hingga sekarang tim secara intensif melakukan pelatihan dan pendampingan 15 orang anggota pokdarwis dalam pelatihan bahasa inggris.

Berdasarkan hasil kegiatan selama pengabdian diketahui bahwasanya peserta sangat antusias selama mengikuti pelatihan bahasa inggris. Para peserta sangat senang dan aktif dalam mengikuti pembelajaran tiap minggunya. Pada pertemuan pertama peserta masih tampak malu dan takut untuk berbicara dengan menggunakan bahasa Inggris. Menyikapi permasalahan umum tersebut, tim pengabdian pelatihan bahasa Inggris selalu memberi semangat dan motivasi kepada peserta agar mereka berani dan percaya diri ketika berbicara dengan bahasa Inggris. Tim juga selalu mengemas kegiatan pelatihan dengan menggunakan metode yang aktif, menarik, dan menyenangkan sehingga para peserta menjadi lebih aktif dan termotivasi untuk belajar bahasa Inggris. Hal ini senada dengan komentar salah satu peserta pelatihan bahasa Inggris, Bu lin dimana beliau menjelaskan jika "Pelatihan bahasa Inggris sangat menyenangkan, cara belajarnya juga asyik nggak bosenin, saya dan teman-teman yang lainnya tidak hanya diajari namun kami dituntun untuk menjadi bisa berbahasa Inggris. Selain itu, strategi mengajarnya beda, ya karena cara mengajarnya itu dengan cara berkolaborasi". Selain itu Mas Fendy selaku koodinator pokdarwis juga menuturkan "Alhamdulillah saya bersyukur sekali dengan adanya pelatihan bahasa inggris yang dilakukan oleh tim pengabdian dari Universitas Negeri Malang. Dengan adanya pelatihan bahasa inggris ini saya berharap bisa mendukung dalam proses pengembangan desa wisata desa Kemloko ini, sebab desa Kemloko ini sudah sering dikunjungi oleh wisatawan dari luar negeri dan rata-rata yang berkunjung ini menggunakan bahasa inggris. Nanti jika ada tamu, warga sini ditanya dengan bahasa inggris tidak bisa menjawab, setidaknya kita bisa mengerti bahasa inggris yang digunakan sehari hari misal kata sapaan good morning, how are you seperti itu" ujarnya.
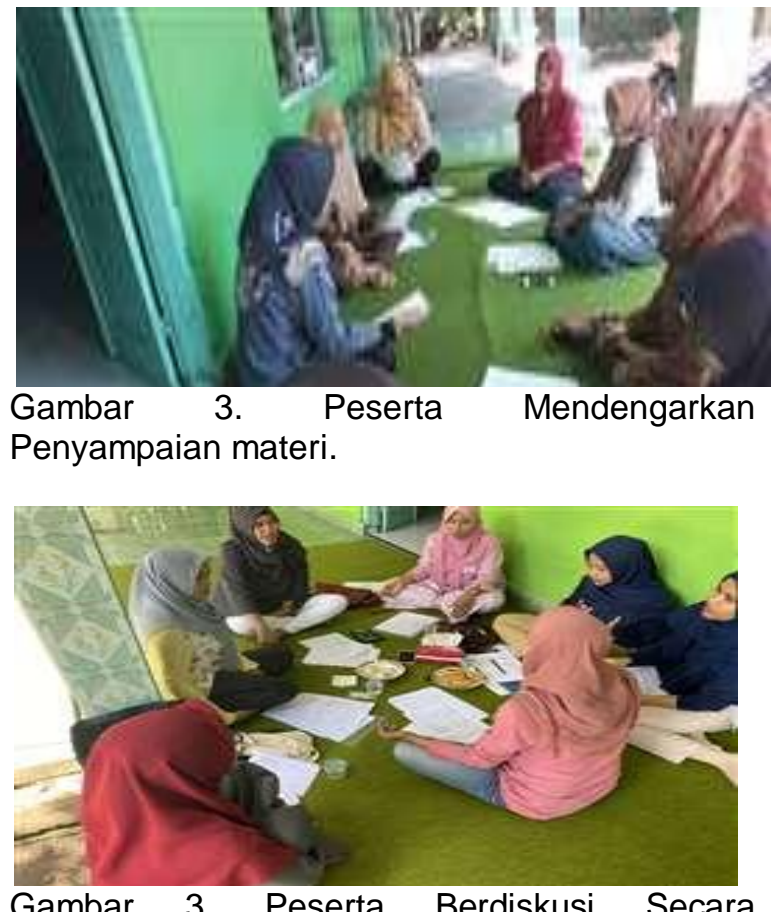

Berkelompok.

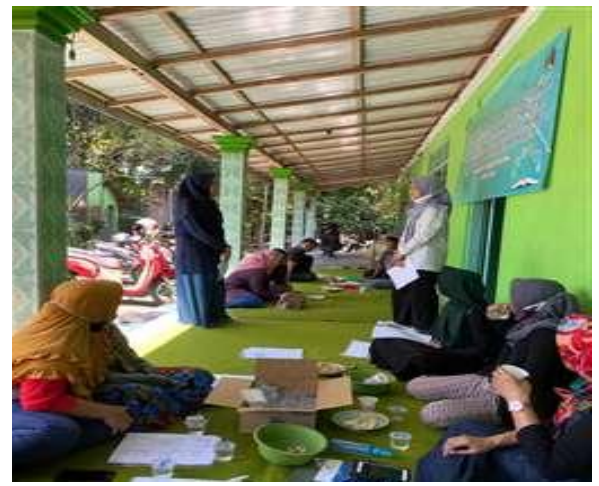

Gambar 4. Peserta Mendemonstrasikan Percakapan Menggunakan Bahasa Inggris. 
Respon baik tidak hanya terlihat dari peserta, pihak perangkat Desa Kemloko juga sangat mendukung kegiatan pengabdian. Perangkat desa menerima tim pengabdian Universitas Negeri Malang dengan respon positif dan sangat membantu keperluan-keperluan apabila ada yang dibutuhkan dari tim pengabdian. Perangkat desa menggerakkan masyarakat untuk menjadi peserta dalam mengikuti "Pelatihan Bahasa Inggris For Tourism".

Sebagai tahapan akhir kegiatan pengabdian ini peserta diberikan tes untuk mengukur ketercapaian pengetahuan bahasa inggris yang telah diberikan selama 8 kali pertemuan. Berdasarkan hasil tes diketahui bahwasanya rata-rata nilai yang yang ditunjukkan oleh peserta adalah 72,28 . Nilai tertinggi yang dicapai oleh peserta yaitu 80, sedangkan nilai terendahnya yaitu 60. Adapun distribusi frekuensi dari pencapaian hasil tes peserta sebagai berikut:

$\mathrm{K}=1+3,3 \times \log \mathrm{N}$

$\mathrm{K}=1+3,3 \times 1,176$

$\mathrm{K}=1+3,88$

$\mathrm{K}=4,88=5$

Jadi kelas intervalnya adalah 5

$\mathrm{i}=$ (nilai tertinggi-nilai terendah $) / \mathrm{K}$

$\mathrm{i}=(80-60) / 5=20 / 5=4$

Jadi interval kelasnya adalah 4

Tabel 1. Distribusi Frekuensi Hasil Tes

\begin{tabular}{cccc}
\hline $\begin{array}{c}\text { Kelas } \\
\text { Interval }\end{array}$ & Frekuensi & $\begin{array}{c}\text { Frek. } \\
\text { Relatif }\end{array}$ & $\%$ \\
\hline $60-63$ & 1 & 7 & 7 \\
$64-67$ & 3 & 20 & 27 \\
$68-71$ & 2 & 13 & 40 \\
$72-75$ & 6 & 40 & 80 \\
$>76$ & 3 & 20 & 100 \\
Total & $\mathbf{1 5}$ & $\mathbf{1 0 0}$ & \\
& & &
\end{tabular}

Berdasarkan hasil distribusi frekuensi tersebut di atas diketahui bahwa Sebagian besar peserta yaitu 6 orang memperoleh nilai di rentang nilai 72-75. Hasil nilai tersebut menyimpulkan bahwa peserta telah memahami materi pelatihan bahasa inggris dengan baik.

Sebagai wujud rasa terimakasih warga Kemloko dengan kegiatan pengabdian ini, seluruh panitia dan peserta disuguhi oleh pertunjukan kesenian Reog
Bulkio yang notabene merupakan ikon Desa Kemloko. Pertunjukan ini sebagai simbol bahwa acara pengabdian telah berakhir dengan hasil yang memuaskan.

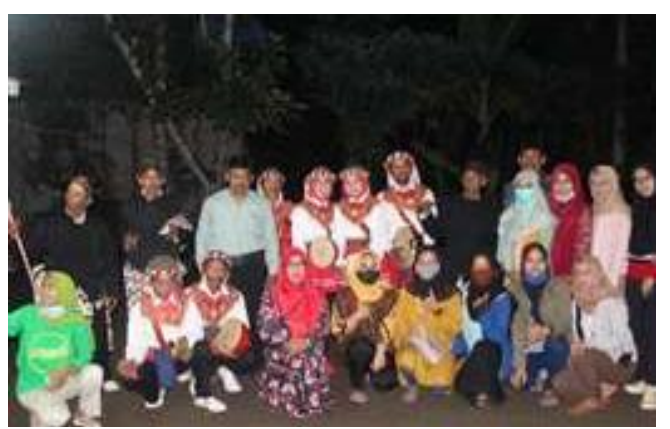

Gambar 5. Penampilan Reog Bulkio Sebagai Penutup Kegiatan Pengabdian.

Kegiatan pemberdayaan masyarakat Desa Kemloko sangat perlu dikembangkan karena desa ini memiliki potensi sebagai desa wisata. Pemberdayaan masyarakat dapat dijadikan strategi sebagai upaya pembangunan masyarakat walaupun dalam penerapan di lapangan belum berjalan dengan maksimal (Noor, 2011) dan Sumodiningrat (2004). Kegiatan pemberdayaan masyarakat dapat berhasil dengan cara melakukan pembangunan yang tidak hanya berfokus pada nilai ekonomi, namun lebih kepada pembangunan yang bersifat sosial dan budaya (Andriyani et al., 2017) dan Pitana (2005). Salah satu bentuk pemberdayaan yang perlu dilakukan adalah peningkatan kualitas Sumber Daya Manusia (SDM). Menurut Kurniawati et al., (2013) pemberdayaan masyarakat dapat dijadikan upaya untuk mewujudkan program mandiri dan proses melepas diri dari kemiskinan dan keterbelakangan. Masyarakat perlu diberi pemberdayaan supaya siap menerima tantangan baru dari pembentukan desa wisata. Adapun tujuan akhir dari pemberdayaan masyarakat menurut Harahap (2012) yaitu memulihkan jati diri manusia disesuaikan dengan harkat dan martabat supaya menjadi pribadi yang menarik, mandiri, dan merdeka dari paksaan orang lain. Konteks menarik dapat dilihat dari keberagaman manusia. Mandiri dilihat dari kemampuan menjadi contoh yang baik bagi diri sendiri maupun sesama. Dan yang terakhir merdeka dilihat dari 
kemampuan terbebas dari genggaman internal maupun eksternal dunia.

Pemberdayaan

memerlukan proses untuk merangkai langkah-langkah mengubah lapisan masyarakat dari yang belum atau kurang berdaya menjadi lebih berdaya (Sulistiyani, 2004). Dalam mengatasi masalah ini, tim pengabdian Universitas Negeri Malang melihat masih belum mahirnya kemampuan bahasa inggris masyarakat Desa Kemloko sehingga tim berupaya menjawab masalah tersebut. Kegiatan yang dilakukan yaitu melalui pelatihan bahasa inggris. Kegiatan pelatihan Bahasa inggris ini sangat berkaitan dengan kebutuhan anggota kelompok sadar wisata (pokdarwis) Desa Kemloko, yaitu adanya kemampuan berbahasa inggris yang fasih guna menghadapi para wisatawan asing yang datang. Dengan adanya pelatihan ini, diharapkan anggota kelompok sadar wisata (pokdarwis) Desa Kemloko tidak lagi merasa takut dan kebingungan ketika mendapatkan tamu wisatawan asing yang datang. Dengan kegiatan pengabdian ini maka anggota kelompok sadar wisata (pokdarwis) Desa Kemloko akan memiliki pengetahuan dan keterampilan yang lebih mumpuni dalam berbahasa inggris. Sehingga kedepannya desa wisata ini akan semakin unggul dengan anggota kelompok sadar wisata (pokdarwis) yang mumpuni dan berkualitas.

\section{(2)Faktor Pendukung dan Penghambat Kegiatan \\ Proses implementasi kegiatan}

Pengabdian "Pelatihan Bahasa Inggris For Tourism" mengalami berbagai macam hal unik yang dapat dijadikan pengalaman dan pelajaran untuk kegaiatan pengabdian berikutnya. Berbagai macam masalah dan solusi hadir dalam kegiatan pengabdian. Hal ini dapat menambah wawasan baru baik bagi peserta maupun tim yang melaksanakan pengabdian. Adapun faktor pendukung dan penghambat yangt terjadi selama pengabdian berjalan yaitu:

- Faktor Pendukung:

a. Koordinasi dan kerja sama tim yang baik sehingga membuat kegiatan ini berjalan lancar b. Peserta pengabdian memiliki antusias dan semangat belajar yang tinggi walaupun jika dilihat dari segi usia mayoritas sudah tua

c. Perangkat Desa Kemloko berperan aktif dan memberikan bantuan sehingga pengabdian berjalan lancar. Saat penutupan pihak perangkat desa menggelar pertunjukkan Reog Bulkio sebagai ucapan terima kasih kepada tim pengabdian Universitas Negeri Malang.

d. Kegiatan pengabdian berjalan interaktif karena peserta rajin bertanya dan melakukan diskusi. Hal ini memudahkan pemateri karena kegiatan diskusi menjadi tidak monoton satu arah saja.

e. Peserta sangat serius dan rajin mengikuti seluruh rangkaian pengabdian.

- Faktor Penghambat:

a. Tim pengisi materi berasal dari Kota Malang sehingga beberapa kali terlambat untuk sampai ke lokasi.

b. Peserta memiliki kemampuan dasar bahasa inggris yang berbeda-beda sehingga menyulitkan tim dalam memberikan materi. Ada peserta yang sudah relatif tahu dan faham bahasa inggris dasar, ada pula yang belum tahu sama sekali dengan bahasa inggris.

c. Kesibukkan peserta yang berbedabeda sehingga membuat beberapa peserta terlambat hadir dalam kegiatan pengabdian.

\section{KESIMPULAN}

Berdasarkan hasil kegiatan selama pengabdian 8 kali pertemuan diperoleh hasil bahwa anggota pokdarwis merasa sangat antusias dalam mengikuti pelatihan bahasa inggris. Peserta pengabdian merasa mudah memahami konsep bahasa inggris dasar dan termotivasi untuk berlatih karena tim pengabdian menerapkan metode belajar yang aktif, menarik, dan menyenangkan. Rata-rata nilai berdasarkan hasil tes evaluasi akhir adalah 72,28. Nilai tertinggi yaitu 80 , sedangkan nilai terendah yang dicapai oleh peserta yaitu 60. Enam orang peserta pengabdian memperoleh 
nilai antara rentang 72-75 dan tiga orang peserta memperoleh nilai di rentang $>76$. Hasil nilai tersebut menyimpulkan bahwa peserta telah memahami keseluruhan materi pelatihan bahasa inggris dengan baik dan pengabdian masyarakat dikatakan berhasil.

\section{DAFTAR PUSTAKA}

Andriyani, A., Martono, E., Muhamad. 2017. Pemberdayaan Masyarakat Melalui Pengembangan Desa Wisata Dan Implikasinya Terhadap Ketahanan Sosial Budaya Wilayah (Studi Di Desa Wisata Penglipuran Bali), (Online),

(https://journal.ugm.ac.id/jkn/article/ download/18006/15758), diakses pada 20 November 2020. 23(1), 116.

Egar, Ngasbun. 2017. Pemberdayaan Remaja Desa Wisata Bendosari Kecamatan Plantungan Kabupaten Kendal melalui Pelatihan Kepemanduwisataan, (Online), (https://media.neliti.com/media/publi cations/266896-pemberdayaanremaja-desa-wisata-bendosar488b3221.pdf), diakses pada 11 Desember 2019.

Harahap, Erni Febrina. 2012. Pemberdayaan Masyarakat dalam Bidang Ekonomi untuk Mewujudkan Ekonomi Nasional yang tangguh dan Mandiri, (Online), (http://journal.unitas-

pdg.ac.id/downlotfile.php?file=5. Erni
\%20Febrina\%20Harrahap-

Pemberdayaan\%20Masyarakat\%20 DIm\%20Bid.\%20Ekonomi.pdf), diakses pada 20 November 2020. 3(2), 78-96.

Kurniawati, D., Supriyono, B., Hanafi, I. 2013. Pemberdayaan Masyarakat di Bidang Usaha Ekonomi (Studi pada Badan Pemberdayaan Masyarakat Kota Mojokerto), (Online), (http://administrasipublik.studentjour nal.ub.ac.id/index.php/jap/article/vie w/129), diakses pada 20 November 2020. 1(4), 9-14.

Noor, Munawar. 2011. Pemberdayaan Masyarakat, (Online), (https://core.ac.uk/download/pdf/234 022402.pdf), diakses pada 20 November 2020. 1(2), 87-99.

Nuryanti, Wiendu. 1993. Concept, Perspective and Challenges, Makalah bagian dari Laporan Konferensi Internasional mengenai Pariwisata Budaya. Yogyakarta: Gadjah Mada University Press.

Pitana, I Gede dan Gayatri. 2005. Sosiologi Pariwisata. Yogyakarta: Penerbit Andi.

Sulistiyani, A. T. 2004. Kemitraan dan ModelModel Pemberdayaan. Yogyakarta: Gava Media.

Sumodiningrat, Gunawan. 1999. Pemberdayaan Masyarakat dan Jaring Pengaman Sosial. Gramedia: Jakarta.

Yoeti, Oka A. 1991. Pengantar IImu Pariwisata. Bandung: Angkasa. 